\title{
Feelings of Existential Fulfilment and Burnout Among Secondary School Teachers
}

Citation for published version (APA):

Loonstra, B., Brouwers, A., \& Tomic, W. (2009). Feelings of Existential Fulfilment and Burnout Among Secondary School Teachers. Teaching and Teacher Education, 25(5), 752-757.

https://doi.org/10.1016/j.tate.2009.01.002

DOI:

10.1016/j.tate.2009.01.002

Document status and date:

Published: 01/07/2009

Document Version:

Peer reviewed version

Please check the document version of this publication:

- A submitted manuscript is the version of the article upon submission and before peer-review. There can be important differences between the submitted version and the official published version of record. People interested in the research are advised to contact the author for the final version of the publication, or visit the DOI to the publisher's website.

- The final author version and the galley proof are versions of the publication after peer review.

- The final published version features the final layout of the paper including the volume, issue and page numbers.

Link to publication

\section{General rights}

Copyright and moral rights for the publications made accessible in the public portal are retained by the authors and/or other copyright owners and it is a condition of accessing publications that users recognise and abide by the legal requirements associated with these rights.

- Users may download and print one copy of any publication from the public portal for the purpose of private study or research.

- You may not further distribute the material or use it for any profit-making activity or commercial gain

- You may freely distribute the URL identifying the publication in the public portal.

If the publication is distributed under the terms of Article 25fa of the Dutch Copyright Act, indicated by the "Taverne" license above, please follow below link for the End User Agreement:

https://www.ou.nl/taverne-agreement

Take down policy

If you believe that this document breaches copyright please contact us at:

pure-support@ou.nl

providing details and we will investigate your claim.

Downloaded from https://research.ou.nl/ on date: 26 Apr. 2023 
Provided for non-commercial research and education use. Not for reproduction, distribution or commercial use.

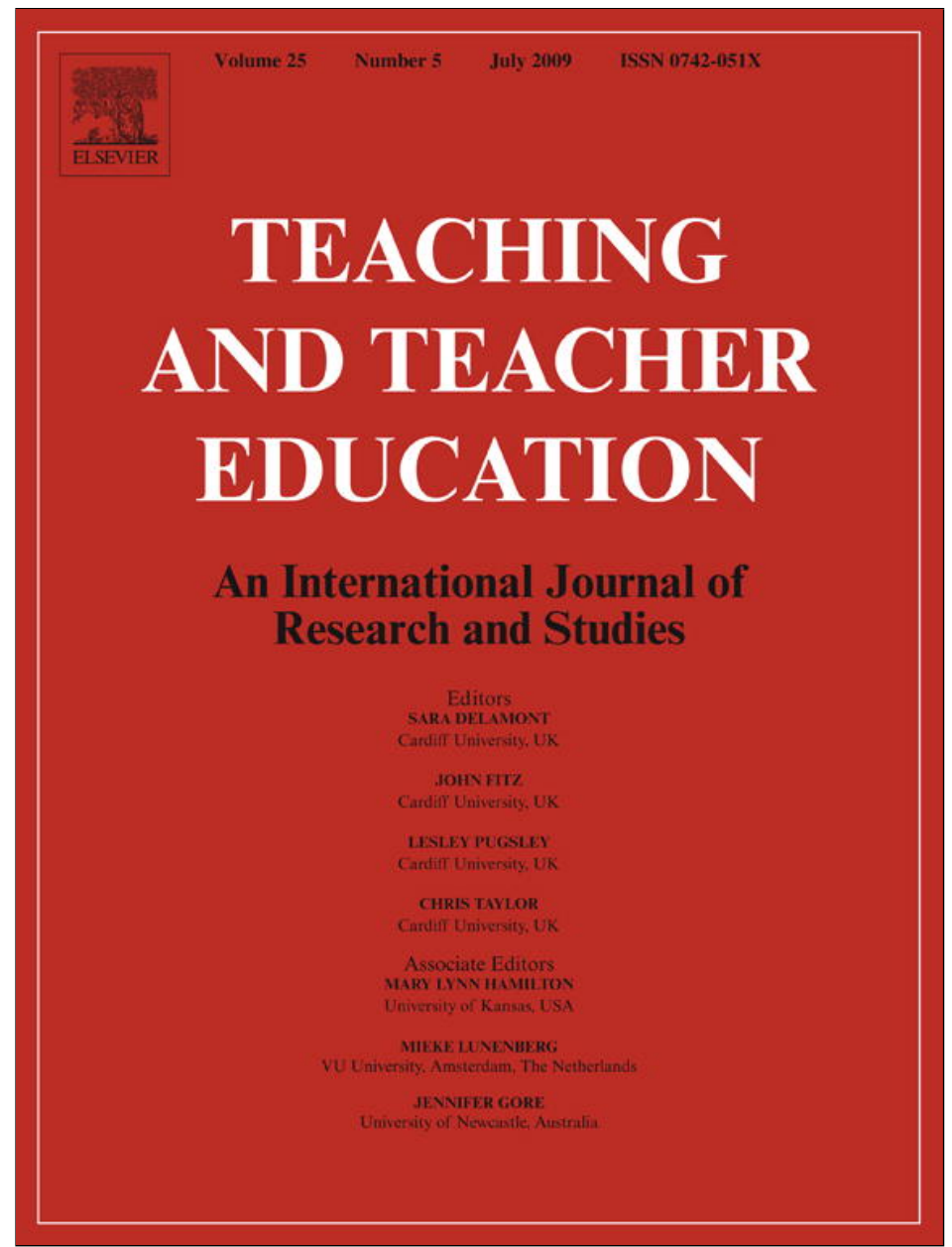

This article appeared in a journal published by Elsevier. The attached copy is furnished to the author for internal non-commercial research and education use, including for instruction at the authors institution and sharing with colleagues.

Other uses, including reproduction and distribution, or selling or licensing copies, or posting to personal, institutional or third party websites are prohibited.

In most cases authors are permitted to post their version of the article (e.g. in Word or Tex form) to their personal website or institutional repository. Authors requiring further information regarding Elsevier's archiving and manuscript policies are encouraged to visit:

http://www.elsevier.com/copyright 


\title{
Feelings of existential fulfilment and burnout among secondary school teachers
}

\author{
Bert Loonstra, André Brouwers, Welko Tomic* \\ Psychology, The Open University, Valkenburgerweg 177, 6419 AT Heerlen, Limburg, The Netherlands
}

\section{A R T I C L E I N F O}

\section{Article history:}

Received 11 September 2007

Received in revised form

26 November 2008

Accepted 6 January 2009

\section{Keywords:}

Existential fulfilment

Self-acceptance

Self-actualization

Self-transcendence

Burnout

Secondary school teachers

\begin{abstract}
A B S T R A C T
Teacher burnout is recognized as a serious problem. In research it has been related to many personspecific variables; one of these, the variable of existential fulfilment, has received very little attention thus far. The present study focuses on the relationship between existential fulfilment and burnout among secondary school teachers in the Netherlands $(N=504)$. Existential fulfilment was made operational by means of the Existential Fulfilment Scale, which distinguishes between three dimensions: self-acceptance, self-actualization, and self-transcendence. A confirmatory factor analysis revealed a threedimensional construct with interdependent dimensions. Burnout was measured by the Dutch version of the Maslach Burnout Inventory for teachers. Negative relationships between the existential fulfilment dimensions on the one hand and the burnout dimensions exhaustion and cynicism on the other were hypothesized, as well as positive relationships between the existential fulfilment dimensions and the burnout dimension professional efficacy. The hypotheses were confirmed, except for the relationships between self-transcendence and exhaustion and self-transcendence and cynicism, which appeared not to be significant. The inquiry demonstrated the importance of existential fulfilment for the prevalence and prevention of burnout among teachers. The study concludes with a discussion of the implications for future research.
\end{abstract}

(c) 2009 Elsevier Ltd. All rights reserved.

\section{Introduction}

Burnout among secondary school teachers has been exposed in research as a serious occupational hazard (Van Horn, Caljé, Schreurs, \& Schaufeli, 1997). The stress levels among teachers are found to surpass the average levels among people working in other client-related professions (Travers \& Cooper, 1993), and the correlations between work load, stress and burnout symptoms are widely recognized (Schaufeli \& Enzmann, 1998). Burnout is a jobrelated syndrome that manifests itself in three symptoms: mental exhaustion, cynicism (formerly labelled 'depersonalization') and reduced professional efficacy (or 'personal accomplishment') (Maslach, 1993). Besides environmental variables that predict burnout phenomena, for example workload, social support and school administration, personality factors have also been identified as significant in the research on teacher burnout; these include personality traits (Cano-Garcia, Padilla-Muñoz, \& Carrasco-Ortiz, 2005), perceived self-efficacy (Brouwers \& Tomic, 2000; Evers, Brouwers, \& Tomic, 2002), existential fulfilment (Tomic, Evers, \& Brouwers, 2004), constructive thinking (Evers, Tomic, \& Brouwers, 2005), and work engagement (Hakanen, Bakker, \& Schaufeli, 2006).

\footnotetext{
* Corresponding author. Tel.: +31 45 5762539; fax: +31 455762939

E-mail address: welko.tomic@ou.nl (W. Tomic).
}

Another line of investigation explores the interplay between personality and environment, such as the social exchange perspective of effort and reward (Bauer et al., 2007; Van Horn, Schaufeli, \& Enzmann, 1999), and self-efficacy in eliciting social support (Brouwers, Evers, \& Tomic, 2001). Intervention programmes focusing on personality factors are likely to be more effective than those focusing on environmental conditions because they appear to be more easily altered than organizational factors (Tomic et al., 2004). Among the personality factors, the concept of perceived self-efficacy is compatible with constructive thinking. Evers et al. (2005) argue that constructive thinking is more fundamental to an individual than are coping strategies, because it relates to underlying thought patterns. In the same way, it can be argued that the existential level of an individual is more fundamental than his or her cognitive level, because the former affects basic motivations and attitudes towards life with its possibilities and limitations. Constructive thinking therefore appears to be rooted in existential fulfilment. The latter construct has been suggested to play an important role in teacher burnout (for instance Längle, 2003). For this reason, we chose to focus on existential fulfilment as a possible predictor of burnout.

Along with many existentially inclined researchers, Pines (1993, 1996, 2000, 2002a, 2002b), postulates a need and search for existential meaning. Existential fulfilment refers to a way of life full of meaning and purpose, and reveals an existential psychological 
approach to life. Characteristic of existential psychology is the attention paid to the boundary experiences of human beings as determinants of human existence (Yalom, 1980). Human existence is confronted with several existential boundaries. To obtain a fulfilled existence, human beings have to overcome the psychological conflicts evoked by these boundaries. Humans have to meet several tasks: they have to accept their own mortality, the limitations of their potentialities, as well as their being only a part of reality. They have to be eager to explore and develop their limited potentialities, and they have to recognize the otherness of the outer world and relate themselves to it. In fulfilling these existential tasks, people find life-meaning, and a fulfilled existence. The three existential tasks can be summarized as self-acceptance, self-actualization, and self-transcendence.

These three notions can be interpreted as basic attitudes to pursue existential fulfilment, and to overcome the psychological conflicts caused by human limitedness. Someone who accepts the self accepts his or her potentialities and intrinsic limitations. Someone who actualizes the self explores and develops his or her possibilities and potentialities for the sake of personal growth in understanding and abilities. Someone who transcends the self recognizes the otherness of the reality beyond the self, looking for respectful relationships with it, deriving life-meaning from these relationships, feeling responsible for them, feeling part of a larger whole, distinguishing interests that surpass self-interests, and being able to see the self in perspective of the outer reality (Loonstra, Brouwers, \& Tomic, 2007).

That is why the concept of existential fulfilment has been reconsidered (Loonstra et al., 2007). Existential fulfilment is understood as the life-purpose that aims at doing full justice to the nature of human existence. Human beings pursue this life goal by accepting the self, by actualizing the self, and by transcending the self. The three dimensions self-acceptance, self-actualization, and self-transcendence have been popularized in humanistic and existential psychological literature. Rogers (1961) contrasts self-acceptance to a behaviour in which individuals pursue values that will bring social approval, affection, and esteem. In this way they try to 'buy love' (Rogers, 1964). As to self-actualization, Maslow (1943) holds it to be the pinnacle of the hierarchy of human needs. He defines the concept as the desire for self-fulfilment, or the tendency to become more and more who one is. Self-transcendence is considered by Frankl (1962) to be the essence of human existence. This spiritual ability enables the individual to make intentional contacts with the world beyond the self, which gives ultimate meaning to life.

The interest in the relationship between existential fulfilment and burnout ensues from the view of healthy psychological functioning that has been developed by existential and humanistic psychology. Frankl (1962) in particular developed an existential perspective on burnout with his psychology of meaning. He introduced the term 'existential vacuum' for a mode of existence without any meaning and purpose, prone to neuroticism and characterized by boredom and attempts to escape such boredom by distraction. The opposite, existential fulfilment, refers to a way of life full of meaning and purpose.

Frankl (1962) was not alone in leaning towards existential significance. People need to believe that they are significant in the larger scene of things. In a more and more secularized environment work has become a frequently chosen alternative source of meaning. According to Pines (1996) this happens particularly in the lives of idealistic and highly motivated individuals. They work hard because they expect their work to make their lives matter in the larger scheme of things and give meaning to their existence. Pines (1993) writes that the cause of burnout lies in our need to believe that our lives are meaningful and that the things we do are useful and important. When individuals fail in these efforts, they are prone to burnout. Burnout emerges out of the experience of meaninglessness. In this framework Pines (1993) describes burnout as growing out of a gradual disillusionment in a quest to derive a sense of existential significance from work.

Längle (2003) explained the genesis of burnout by referring to the concept of existential vacuum and fulfilment. Burnout can be seen as a special form of existential vacuum, or as a deficit of fulfilment, which entails a loss of interest, a lack of initiative, and emotional exhaustion. Burned-out professionals are described as being extrinsically focused on objectives like influence, income, recognition, appreciation, and social acceptance that prevent them from freely dedicating themselves to their job and truly accepting the related responsibility. Research in line with Längle's theory and using a scale that he developed and tested (Längle, Orgler, \& Kundi, 2003) attempted to prove the hypothesized relationship (Nindl, 2001; Tomic et al., 2004). The results were astonishing, but unfortunately the scale was unable to stand up to confirmatory factor analysis (Loonstra, Brouwers, \& Tomic, in press).

The above-mentioned authors have formed the basis for theories about the relationships between the dimensions of existential fulfilment and of burnout, leading to three hypotheses that are broken down into three statements each.

Hypothesis 1. Higher degrees of existential fulfilment predict lower scores on the burnout dimension mental exhaustion. This hypothesis can be subdivided along the lines of the three dimensions of existential fulfilment. Hypothesis 1a says that higher degrees of self-acceptance induce lower scores on mental exhaustion. People who accept themselves and their limitations are less dependent on the acceptance, recognition and appreciation of others. They spend less energy satisfying others and therefore do not run the risk of premature exhaustion. Hypothesis $1 \mathrm{~b}$ says that higher degrees of self-actualization induce lower scores on mental exhaustion. Self-actualization is motivated by internal drives instead of external obligations, work engagement correlates negatively with exhaustion (Schaufeli \& Bakker, 2004). Hypothesis 1c contends that higher degrees of self-transcendence correlate with lower degrees of exhaustion. This is suggested by the reflection that self-transcendence supposes relationships that are inspiring instead of exhausting.

Hypothesis 2. Higher degrees of existential fulfilment predict lower scores on the burnout dimension cynicism. The dependent hypotheses $2 \mathrm{a}, 2 \mathrm{~b}$, and $2 \mathrm{c}$ maintain that higher scores on the three dimensions of fulfilment, i.e. self-acceptance, self-actualization, and self-transcendence, bring about lower scores on cynicism. Cynicism is caused by job frustration. Lack of self-acceptance makes people rely more heavily on the approval of others. If they fail to gain such approval, frustration follows, leading to cynicism. If the job does not make it possible to actualize one's opportunities, selfactualization may function as an inner drive that subordinates the job to a comprehensive life project of self-realization. Without such a drive, frustration may once again result. And finally, if self-transcendence is low, there is only a faint notion of meaning and value beyond the self, which fosters cynicism.

Hypothesis 3. Higher degrees of existential fulfilment predict higher scores on the burnout dimension professional efficacy. The related hypotheses $3 a, 3 b$, and $3 c$ state that higher scores on the three dimensions of fulfilment are accompanied by higher scores on efficacy, for the following reasons. People who accept themselves and their limitations are aware of their finite possibilities. They believe in their efficacy within these limitations; they try to cut their coat to suit their cloth. Moreover, people who actualize their opportunities are self-confident in exploiting their potential, which is a sign of efficacy. Finally, self-transcendence, the sense of meaning in the world beyond the self, may serve as a source of inspiration and strength when performing one's duties. 
It is theoretically important to expand burnout research to a significant plausible factor. Existential fulfilment may contribute to the theory of the onset of burnout among teachers. An adequate theory is of practical value and a prerequisite for developing effective interventions for preventing and alleviating burnout complaints among these professionals.

\section{Method}

\subsection{Participants}

The participants were 504 teachers employed in schools of general secondary education, working in randomly selected schools in The Netherlands. All teachers were eligible for the present study. In all, 275 female teachers (54.7\%) and 229 male teachers (45.3\%) participated. The average age of the teachers was 45.34 years $(S D=10.47)$, ranging from 20 to 64 years old. The mean number of years of teaching experience was $16.03(\mathrm{SD}=10.52)$, ranging from 0 to 41 . The mean number of weekly working hours was 25.19 $(\mathrm{SD}=9.56)$.

This study has been performed among teachers working in general secondary education. The Dutch system has three tracks of education each aimed at a different academic level. After primary school, students - twelve years of age - can pursue prevocational secondary education, which is usually an introduction to middle vocational education. This branch takes four years to complete. Senior general secondary education lasts five years and qualifies students to enter higher professional education. Pre-university education lasts six years and prepares students for academic studies at university level.

All teachers in secondary education must be certified. Firstgrade teacher qualification covers all schools and all classes of university preparatory education and senior general secondary education. A master's degree in the field of teaching and an extra training of teaching are required. Second-grade qualification is limited to the first three school years of secondary education. These teachers need to have a degree of the School of Education which is a four year training at higher professional education level.

\subsection{Measures}

Existential fulfilment. Existential fulfilment, composed of the three dimensions self-acceptance, self-actualization, and selftranscendence, was measured by means of the Existential Fulfilment Scale (EFS) (Loonstra et al., 2007). The EFS consists of 15 items, 5 items for each dimension, measured on a 5-point Likert scale, running from 0 to 4 , meaning 'not at all' to 'fully' relevant to me. The five items about self-acceptance refer to the urge to prove oneself to others, rejection of the self, inner uncertainty, and psychological reliance. For example: 'Often I do things more because I have to than because I want to.' The scores were recoded in order to use them as indications of self-acceptance. The selfactualization items are about intrinsic motivation, the passion of one's own ideals, and feeling free to calmly pursue one's goals. One item is, for instance: 'I remain motivated to go on, even when things are going against me.' The items regarding self-transcendence are about feeling part of a larger, meaningful totality, conceiving a sense of life that transcends personal interests, and being convinced that life is good for something, conceptualized as selftranscendence. In a study of 812 students, the EFS showed an acceptable fit of its factorial structure (Loonstra et al., 2007).

Burnout. The Dutch version of the Maslach Burnout Inventory for teachers (MBI-NL-Ed; Schaufeli \& Van Horn, 1995) was used to assess teachers' burnout level. The instrument consists of twenty items, and is divided into three sub-scales: (1) mental exhaustion
(8 items), (2) cynicism (5 items) and (3) professional efficacy (7 items). Teachers could score items on a 7-point Likert scale, from 'never' to 'always'. It is assumed that teachers will suffer from burnout when their scores on exhaustion and cynicism are high, and the scores on professional efficacy are low. Examples of items indicating exhaustion are 'At the end of the working day I feel empty' and 'I feel tired when I get up in the morning, facing a new working day again'. Examples of cynicism items are 'I have the feeling that I treat some pupils in an impersonal way' and 'I don't really care what will become of my pupils'. Examples of items indicating professional efficacy are 'When I have finished my instruction, I look back on it full of satisfaction' and 'I have the feeling I achieve many things of great value in this job'. The threefactor structure of the Dutch version of the Maslach Burnout Inventory for teachers has been investigated by means of confirmatory factor analysis (Schaufeli, Daamen, \& Van Mierlo, 1994).

\subsection{Procedure}

The questionnaires were mailed to randomly selected schools. Before this, the school principals were telephoned to ask for their co-operation at school level. These preliminary requests were also meant to explain the purpose of the study and the way it had been organized. After the principals approved the request, the questionnaires, the accompanying letters, and the return envelopes were mailed to the principals, who were asked to pass them out to the teachers. The letter of introduction explained the purpose of the study and asked the teachers to participate in it by filling out the self-report questionnaires and sending them back anonymously and individually in the postage-paid envelopes. The researchers guaranteed that the responses remain anonymous and that the responses could not be linked to identifying information. The current study could not lead to the identification of individuals. No individual could be singled out for his or her responses. Three weeks after the first mailing, repeat letters were sent to the principals asking them to handover these letters to the teachers.

\section{Results}

In order to determine whether the three existential fulfilment factors showing a relationship with burnout, i.e. self-acceptance, self-actualization and self-transcendence, reflect three correlated factors, confirmatory factor analysis was conducted using the AMOS 6.1 computer programme. A three-factor model was formulated in which the items used to measure self-acceptance, self-actualization and self-transcendence were supposed to load on their respective three factors. In order to decide whether the threefactor model fits the data, the Comparative Fit Index (CFI) was used. Research findings show that the CFI is relatively independent of the sample size taken at random (Bentler, 1990). When the value of CFI reached the criterion of .90 recommended by Bentler and Bonett (1980), it was assumed that the model could not be significantly improved.

Results of the confirmatory factor analysis showed that the three-factor correlated model fits the data quite well (null model: $\chi^{2}(105)=2569.24$; three-factor correlated model: $\chi^{2}(87)=345.14$, $\mathrm{CFI}=.90)$. This three-factor correlated model fits the data significantly better than the one-factor model $\left(\chi^{2}(90)=1184.55\right.$, $\left.\mathrm{CFI}=.56 ; \Delta \chi^{2}(3)=839.41, p<.001\right)$; the best-fitting two-factor model: the model with the self-transcendence items was allowed to load on one factor, the self-acceptance and self-actualization items were allowed to load on the other factor, and the factors were allowed to correlate $\left(\chi^{2}(89)=548.76, \mathrm{CFI}=.81 ; \Delta \chi^{2}(2)=203.62\right.$, $p<.001)$; and the three-factor uncorrelated model: the model in 
which the factors were not allowed to correlate with each other $\left(\chi^{2}(90)=532.01, \mathrm{CFI}=.82 ; \Delta \chi^{2}(3)=186.87, p<.001\right)$.

Table 1 shows the standardized regression coefficients of the three-factor correlated model that can be interpreted as factor loadings. The lowest value of the standardized regression coefficients was .49 , which implies that the items loaded well on the factors in question.

After scaling, the means, standard deviations, and intercorrelations were computed (see Table 2). Reliability analysis resulted in Cronbach's Alphas of .91 for exhaustion, .66 for cynicism, .79 for professional efficacy, .78 for self-acceptance, .71 for self-actualization, and .86 for self-transcendence.

Table 2 showed that the three existential fulfilment factors were significantly and positively related to each other, except for the relationship between self-acceptance and self-transcendence. Selfacceptance as well as self-actualization were significantly and negatively related to the cynicism and exhaustion dimensions of burnout, and significantly but positively related to efficacy. Selftranscendence showed to be significantly and negatively related to cynicism and significantly and positively related to efficacy, but showed no significant relationship to exhaustion. The total number of working hours seemed only to be significantly and positively related to the burnout dimensions, but not to the existential fulfilment factors. Although scores on the exhaustion and efficacy dimensions of burnout as well as the three existential fulfilment factors showed no significant gender differences, men had significantly higher scores on cynicism than women.

Hierarchical regression analyses were carried out in order to investigate to what extent the existential fulfilment factors explained burnout level. In doing so, the variables gender, age, and the number of hours of the teacher's appointment were statistically controlled. With each burnout dimension as a dependent variable, these control variables were first added to the regression equation (step 1), followed by the independent variables, i.e. the existential fulfilment factors self-acceptance, self-actualization, and selftranscendence (step 2).

The results of the hierarchical regression analyses-see Table 3-showed that self-acceptance as well as self-actualization and

Table 1

Completely standardized CFA-solution of the three-factor correlated EFS-dimensions $(N=504)$.

\begin{tabular}{|c|c|c|c|c|}
\hline \multirow{2}{*}{$\begin{array}{l}\text { Item } \\
\text { no. }\end{array}$} & \multirow{2}{*}{ Item } & \multicolumn{3}{|c|}{ Factor } \\
\hline & & 1 & 2 & 3 \\
\hline \multicolumn{5}{|c|}{ Self-acceptance } \\
\hline 1 & $\begin{array}{l}\text { I often feel uncertain about the impression I make on other } \\
\text { people }\end{array}$ & -.71 & - & - \\
\hline 8 & I often feel I have to prove myself & -.68 & - & - \\
\hline 11 & I find it very hard to accept myself & -.64 & - & - \\
\hline 12 & $\begin{array}{l}\text { I am often engaged in activities to show my true worth to other } \\
\text { people }\end{array}$ & -.55 & - & - \\
\hline 3 & I do a lot of things that I would actually rather not do & -.49 & - & - \\
\hline \multicolumn{5}{|c|}{ Self-actualization } \\
\hline 5 & Deep inside I feel free & - & & - \\
\hline 7 & Even in busy periods I experience feelings of inner calm & - & & - \\
\hline 14 & I completely approve of the things that I do & - & & - \\
\hline 2 & I'll remain motivated to carry on even in times of bad luck & - & .55 & - \\
\hline 15 & I draw my inspiration from my ideals & - & .50 & - \\
\hline \multicolumn{5}{|c|}{ Self-transcendence } \\
\hline 6 & I think I am part of a meaningful entity & - & - & .88 \\
\hline 4 & I feel incorporated in a larger meaningful entity & - & - & .78 \\
\hline 9 & It is my opinion that there must be some reason for my life & - & - & .76 \\
\hline 13 & $\begin{array}{l}\text { I think my life has such a deep meaning that it surpasses my } \\
\text { personal interests }\end{array}$ & - & - & .67 \\
\hline 10 & $\begin{array}{l}\text { I have experienced that there is more in life than I can perceive } \\
\text { with my senses }\end{array}$ & - & - & .66 \\
\hline
\end{tabular}

self-transcendence were significantly and positively related to the professional efficacy dimension of burnout $(\beta=.17, \quad p<.001$; $\beta=.36, p<.001 ; \beta=.11, p<.01$ respectively). Only self-acceptance and self-actualization (i.e. not self-transcendence) were significantly and negatively related to the exhaustion $(\beta=-.50, p<.001$; $\beta=-.18, p<.001 ; \beta=.04, p>.05$ respectively), as well as the cynicism $(\beta=-.40, p<.001 ; \beta=-.09, p<.01 ; \beta=-.04, p>.05$ respectively) dimensions of burnout. The total of the variance explained by the three existential fulfilment factors was 35\% for exhaustion, $20 \%$ for cynicism, and $25 \%$ for professional efficacy.

\section{Discussion}

All three main hypotheses on the relationships between the existential fulfilment dimensions and symptoms of burnout were confirmed. Existential fulfilment explained a significant percentage of the burnout dimensions exhaustion, cynicism, and professional efficacy, with negative $\beta \mathrm{s}$ in the equations with exhaustion and cynicism indicating negative relationships between fulfilment and these burnout dimensions, and positive $\beta \mathrm{s}$ in the equations with efficacy indicating a positive relationship between fulfilment and this burnout dimension.

Confirmation of relationships between the existential fulfilment dimensions and symptoms of burnout can be explained as follows. Teachers who accept themselves and their limitations to some extent do not lose much energy in creating situations in which they receive an amount of extra appreciation they required. Rather, they can concentrate themselves more fully on the job they have to do, and have therefore more chance to actualize themselves in the challenges of working with students and learning objectives. The internal drive, typical for self-actualized individuals, is related to a greater amount of work engagement, which is found to be protective for the arising of mental exhaustion (e.g., Laschinger, Wong, \& Gredo, 2006; Schaufeli \& Bakker, 2004).

As to the sub-hypotheses, the situation is somewhat more nuanced. Self-acceptance and self-actualization contributed significantly to explaining the variance of exhaustion, cynicism, and professional efficacy. This confirms sub-hypotheses $1 \mathrm{a}, 1 \mathrm{~b}, 2 \mathrm{a}, 2 \mathrm{~b}$, $3 \mathrm{a}$, and $3 \mathrm{~b}$. Although self-acceptance and self-actualization were both related to burnout, it was a somewhat different story when it comes to the existential fulfilment dimension self-transcendence. Self-transcendence did not contribute to explaining the variance of both exhaustion and cynicism, so sub-hypotheses $1 \mathrm{c}$ and 2c have not been confirmed. Yet hypothesis $3 c$ has been confirmed, which means that self-transcendence contributed significantly to explaining the variance of professional efficacy.

The question remains why no relationship was found between self-transcendence on the one hand and exhaustion and cynicism on the other? Maybe it is private conviction that fosters a sense of meaning in life, with no impact on working life. Still, self-transcendence does relate to professional efficacy. It may be that selftranscendence enhances self-confidence, which in its turn promotes efficacy even in a professional context. Unlike self-transcendence, self-acceptance and self-actualization do affect the burnout dimensions exhaustion and cynicism. Apparently, these fulfilment dimensions influence the professional situation more than self-transcendence does. Personal experience is so closely involved in self-acceptance and self-actualization that it is directly related to the measures of exhaustion and cynicism.

Our study has some limitations. First, our study is limited by its cross-sectional design. Some reservations must be expressed as to the direction of causation. The relationships shown do not reveal anything conclusive about causal direction, however. The theoretical justification of the hypotheses indicates that existential fulfilment influences burnout, but one can also imagine influences 
Table 2

Means and standard deviations of the variables and correlations between the variables $(N=504)$.

\begin{tabular}{|c|c|c|c|c|c|c|c|c|c|c|c|c|c|}
\hline & & M & SD & 1 & 2 & 3 & 4 & 5 & 6 & 7 & 8 & 9 & 10 \\
\hline 1 & Gender & - & - & - & & & & & & & & & \\
\hline 2 & Age & 45.34 & 10.47 & $-.11^{*}$ & - & & & & & & & & \\
\hline 3 & Number of years working as a teacher & 16.04 & 10.52 & $-.14^{* *}$ & $.68^{* *}$ & - & & & & & & & \\
\hline 4 & Number of working hours per week & 25.19 & 9.56 & $-.26^{* *}$ & .07 & .07 & - & & & & & & \\
\hline 5 & Self-acceptance & 2.81 & .77 & -.08 & .07 & .07 & -.07 & - & & & & & \\
\hline 6 & Self-actualization & 2.56 & .67 & .06 & .07 & -.01 & .00 & $.46^{* *}$ & - & & & & \\
\hline 7 & Self-transcendence & 2.24 & 1.05 & .09 & -.01 & -.07 & -.06 & .03 & $.37^{* *}$ & - & & & \\
\hline 8 & Mental exhaustion & 2.03 & 1.24 & -.01 & .03 & .05 & $.11^{*}$ & $-.58^{* *}$ & $-.38^{* *}$ & -.05 & - & & \\
\hline 9 & Cynicism & 1.08 & .82 & $-.20^{* *}$ & .04 & .04 & $.11^{*}$ & $-.43^{* *}$ & $-.29 * *$ & $-.11^{*}$ & $.52^{* *}$ & - & \\
\hline 10 & Professional efficacy & 4.20 & .83 & .02 & -.05 & -.07 & $.11^{*}$ & $.32^{* *}$ & $.47^{* *}$ & $.25^{* *}$ & $-.27^{* *}$ & $-.33^{* *}$ & - \\
\hline
\end{tabular}

Note: ${ }^{*} p<.05$; $^{* *} p<.01$.

moving in the opposite direction: a large number of burnout complaints lead to diminished existential fulfilment. When a teacher is subject to strict demands from his or her superiors and only poor appreciation from pupils and students, his or her selfacceptance may be undermined. And when the work environment does not offer opportunities for personal development and growth, self-actualization may be diminished. Both negative examples can also be turned around and presented positively. It is likely that the factors interact.

The direction of causation requires further investigation. Future longitudinal studies are needed to evaluate the possibility of a causal relationship between existential fulfilment and teacher burnout. A better understanding of existential fulfilment - self-acceptance, selfactualization and self-transcendence - leading to teacher burnout is essential. It is therefore important to conduct future studies.

In addition to longitudinal studies, it is recommended to investigate causal relationships using experimental designs in order to test the psychological impact of interventions. One possible intervention is existential fulfilment approach outlined by Längle (2004). Possibly, it could be worthwhile to make this approach suitable for teachers. In a training setting Längle explores the importance of meaning and its impact on mental health. First, an overview of a meaningful life is provided which helps localize the requirements for attaining meaning and reveal practical steps for its attainment. Second, a deeper look is necessary at the structure of our existence from the theoretical perspective of existential fulfilment. Third, the practical elements are shown for a fulfilling life through the training approach. These steps are intended to illuminate the possibilities for growth in one's own existential fulfilment and provide skills to manage the question of meaning both personally and professionally. This approach highlights the basic structure of a fulfilling existence, which is the criterion for and outcome of mental health.

Another possible intervention aimed at prevention of burnout, could be a mindfulness-based stress reduction (MBSR) training programme, supplemented with cognitive elements aimed to help teachers reflect on existential aspects of life and work. Studies have shown that the MBSR-programme can help to diminish psychosomatic symptoms among a broad spectrum of people working in a number of different occupations (Chang et al., 2004; Shapiro, Astin, Bishop, \& Cordova, 2005). In a pilot study Napoli (2004) showed that teachers who followed the MBSR-programme improved in their abilities to deal with conflict and anxiety, whereby they were less prone to experience a chronic stress level, eventually resulting in burnout. Originally, the MBSR-programme was an eight-week training course consisting of two and a half hour sessions that focus on learning how to relax attentively (Kabat-Zinn, 1990). Later, the programme was supplemented with cognitive techniques to suit patients suffering from depression (Teasdale, Segal, \& Williams, 1995). Since existential aspects of life and work may have a significant impact on feelings of psychological well-being, it is important to extend the MBSR-programme with cognitive elements which take existential issues into account. Such a programme could be a meaningful part of the curriculum for student teachers as well as a module intended to promote the professional development of teachers.

A second limitation of the current study was that the Existential Fulfilment Scale has not, as yet, been fully validated. The factorial validity has been confirmed, but not its external validity. The results of this inquiry may be regarded as the first step in the process of external validation. Further validation is required. The remarkable results of the inquiry should be replicated among the same and other occupational groups.

Third, measures in our study were based on self-reports, and we do not know the extent to which these self-reports accurately reflect existential fulfilment and burnout assessed in the survey. Naturally, the results of the present study on the association between existential fulfilment and burnout should be regarded with caution, but there are no indications that these findings solely reflect biased respondent reporting. The findings of the survey could be used to generate hypotheses for future research.

However, in spite of the limitations, our study has several important strengths. First, as we satisfied a number of Guglielmi's (2001) methodological criteria, the study uses measures whose psychometric properties are known, making it possible to compare findings across studies. Second, we also applied an appropriate multivariate data-analytic strategy, i.e. hierarchical regression. Third, as the typical teacher burnout study is essentially atheoretical according to Guglielmi (2001), we adopted a theoretical framework that would help to organize research findings across investigations. Theoretical research will also be of use when developing interventions for teachers aimed at preventing and reducing burnout complaints. Fourth, in addition we used quite a large sample, which is unusual in burnout research. To our

Table 3

Results of hierarchical regression analysis for the predicting variables of emotional exhaustion, depersonalization and personal accomplishment $(N=504)$.

\begin{tabular}{|c|c|c|c|c|c|c|}
\hline \multirow[t]{2}{*}{ Independent variables } & \multicolumn{2}{|c|}{$\begin{array}{l}\text { Mental } \\
\text { exhaustion }\end{array}$} & \multicolumn{2}{|c|}{ Cynicism } & \multicolumn{2}{|c|}{$\begin{array}{l}\text { Professional } \\
\text { efficacy }\end{array}$} \\
\hline & Beta & $\Delta R^{2}$ & Beta & $\Delta R^{2}$ & Beta & $\Delta R^{2}$ \\
\hline Step 1 & & .02 & & $.05^{* * *}$ & & .02 \\
\hline Gender & -.02 & & $-.21^{* * *}$ & & .01 & \\
\hline Age & $.08^{*}$ & & .05 & & $-.10^{* *}$ & \\
\hline $\begin{array}{l}\text { Number of working hours per } \\
\text { week }\end{array}$ & .07 & & .04 & & $.13^{* * *}$ & \\
\hline Step 2 & & $.35^{* * *}$ & & $.20^{* * *}$ & & $.25^{* * *}$ \\
\hline Self-acceptance & $-.50^{* * *}$ & & $-.40^{* * *}$ & & $.17^{* * *}$ & \\
\hline Self-actualization & $-.18^{* * *}$ & & $-.09^{* *}$ & & $.36^{* * *}$ & \\
\hline Self-transcendence & .04 & & -.04 & & $.11^{* *}$ & \\
\hline F-total for the equation & & $45.85^{* * *}$ & & $26.62^{* * *}$ & & $28.66^{* * *}$ \\
\hline
\end{tabular}

Note. ${ }^{*} p<.05 ;{ }^{* *} p<.01 ;{ }^{* * *} p<.001$. 
knowledge, the current study has a larger number of participants than previously reported studies regarding existential fulfilment and teacher burnout (Nindl, 2001). 504 teachers employed in schools of general secondary education responded to our questionnaire. Fifth, the observed association between existential fulfilment and teacher burnout was statistically significant and large enough to suggest that the findings could be meaningful.

The present study shows that existential fulfilment is associated with burnout dimensions. A high level of existential fulfilment goes along with low burnout scores. The important role existential fulfilment plays in the prevalence of teacher burnout, which was observed in some studies (Nindl, 2001; Tomic et al., 2004), has been confirmed. Further investigation of the prevalence, causes, consequences, and management of teacher burnout is needed.

\section{References}

Bauer, J., Unterbrink, T., Hack, A., Pfeifer, R., Buhl-Griesshaber, V., Müller, U., et al. (2007). Burnout and effort-reward-imbalance in a sample of 949 German teachers. International Archives of Occupational and Environmental Health, 80(5), 433-441.

Bentler, P. M. (1990). Comparative fit indexes in structural models. Psychological Bulletin, 107, 238-246.

Bentler, P. M., \& Bonett, D. G. (1980). Significance tests and goodness of fit in the analysis of covariance structures. Psychological Bulletin, 88, 588-606

Brouwers, A., Evers, W. J. G., \& Tomic, W. (2001). Self-efficacy in eliciting social support and burnout among secondary-school teachers. Journal of Applied Social Psychology, 31(7), 1474-1491.

Brouwers, A., \& Tomic, W. (2000). A longitudinal study of teacher burnout and perceived self-efficacy in classroom management. Teaching and Teacher Education, 16(2), 239-253.

Cano-Garcia, F. J., Padilla-Muñoz, E. M., \& Carrasco-Ortiz, M. A. (2005). Personality and contextual variables in teacher burnout. Personality and Individual Differences, 38(4), 929-940.

Chang, V. Y., Palesh, O., Caldwell, R., Glasgow, N., Abramson, M., Luskin, F., et al. (2004). The effects of a mindfulness-based stress reduction programme on stress, mindfulness self-efficacy, and positive states of mind. Stress and Health, 20(3), 141-147.

Evers, W. J. G., Brouwers, A., \& Tomic, W. (2002). Burnout and self-efficacy: a study on teachers' beliefs when implementing an innovative educational system in the Netherlands. British Journal of Educational Psychology, 72, 227-243.

Evers, W., Tomic, W., \& Brouwers, A. (2005). Constructive thinking and burnout among secondary school teachers. Social Psychology of Education, 8, 425-439.

Frankl, V. E. (1962). Psychiatry and man's quest for meaning. Journal of Religion and Health, 1(2), 93-103.

Guglielmi, R. S. (2001). Teacher stress and burnout: methodological perspectives. In N. J. Smelser, \& P. B. Baltes (Eds.), International encyclopaedia of the social \& behavioural sciences, Vol. 24 (pp. 15465-15468). Oxford: Elsevier Science.

Hakanen, J. J., Bakker, A. B., \& Schaufeli, W. B. (2006). Burnout and work engagement among teachers. Journal of School Psychology, 43(6), 495-513.

Kabat-Zinn, J. (1990). Full catastrophe living: Using the wisdom of your body and mind to face stress, pain, and illness. New York: Delacourt.

Längle, A. (2003). Burnout - existential meaning and possibilities of prevention. European Psychotherapy, 4(1), 107-121.

Längle, A. (2004). The search for meaning in life and the existential fundamental motivations. Existential Analysis, 16(1), 2-14.
Längle, A., Orgler, C., \& Kundi, M. (2003). The existence scale: a new approach to assess the ability to find personal meaning in life and to reach existential fulfilment. European Psychotherapy, 4(1), 135-146.

Laschinger, H. K. S., Wong, C. A., \& Gredo, P. (2006). The impact of staff nurse empowerment on person-job fit and work engagement/burnout. Nursing Administration Quarterly, 30(4), 358-367.

Loonstra, B., Brouwers, A., \& Tomic, W. (2007). Conceptualization, construction and validation of the existential fulfilment scale. European Psychotherapy, 7(1), 5-18.

Loonstra, B., Brouwers, A., Tomic, W. The factorial validity of scores on Längle's Existence Scale, in press.

Maslach, C. (1993). Burnout: a multidimensional perspective. In W. B. Schaufeli, C. Maslach, \& T. Marek (Eds.), Professional burnout: Recent developments in theory and research (pp. 19-32). Washington, DC: Taylor \& Francis.

Maslow, A. H. (1943). A theory of human motivation. Psychological Review, 50, 370-396.

Napoli, M. (2004). Mindfulness training for teachers: a pilot program. Complementary Health Practice Review, 9(1), 31-42.

Nindl, A. (2001). Zwischen existentieller Sinnerfüllung und Burnout. Eine empirische Studie aus existenzanalytischer Perspektive. [Between existential fulfilment and burnout. An empirical study from an existential analytic perspective.]. Existenzanalyse, 1(1), 15-23.

Pines, A. M. (1993). Burnout. In L. Goldberger, \& S. Breznitz (Eds.), Handbook of stress: Theoretical and clinical aspects (2nd ed.). (pp. 386-402) New York: Free Press.

Pines, A. M. (1996). Couple burnout: Causes and cures. New York: Routledge.

Pines, A. M. (2000). Treating career burnout: a psychodynamic existential perspective. Journal of Clinical Psychology/In Session: Psychotherapy in Practice, 56(5), 633-642.

Pines, A. M. (2002a). Teacher burnout: a psychodynamic existential perspective. Teachers and Teaching: Theory and Practice, 8(2), 121-140.

Pines, A. M. (2002b). A psychoanalytic-existential approach to burnout: demonstrated in the cases of a nurse, a teacher, and a manager. Psychotherapy: Theory, Research, Practice, Training, 39(1), 103-113.

Rogers, C. R. (1961). On becoming a person: a therapist's view of psychotherapy. Boston: Houghton Mifflin.

Rogers, C. R. (1964). Toward a modern approach to values: the valuing process in the mature person. Journal of Abnormal and Social Psychology, 68, 160-167.

Schaufeli, W. B., \& Bakker, A. B. (2004). Job demands, job resources, and their relationship with burnout and engagement: a multi-sample study. Journal of Organizational Behavior, 25(3), 293-315.

Schaufeli, W. B., Daamen, J., \& Van Mierlo, H. (1994). Burnout among Dutch teachers: an Mbi-validity study. Educational and Psychological Measurement, 54(3), 803-812.

Schaufeli, W. B., \& Enzmann, D. (1998). The burnout companion to study and practice: a critical analysis. London/Philadelphia: Taylor \& Francis.

Schaufeli, W. B., \& Van Horn, J. E. (1995). Maslach Burnout Inventory voor leraren (MBI-NL-Le). Voorlopige handleiding. [MBI for teachers. Preliminary manual.]. Utrecht: Pago, Utrecht University.

Shapiro, S. L., Astin, J. A., Bishop, S. R., \& Cordova, M. (2005). Mindfulness-based stress reduction for health care professionals: results from a randomized trial. International Journal of Stress Management, 12(2), 164-176.

Teasdale, J. D., Segal, Z., \& Williams, J. M. G. (1995). How does cognitive therapy prevent depressive relapse and why should attentional control (mindfulness) training help? Behavioural Research Therapy, 33(1), 25-39.

Tomic, W., Evers, W. J. G., \& Brouwers, A. (2004). Existential fulfilment and teacher burnout. European Psychotherapy, 5(1), 65-74.

Travers, C. J., \& Cooper, C. L. (1993). Mental health, job satisfaction and occupational stress among UK teachers. Work \& Stress, 7(3), 203-219.

Van Horn, J. E., Caljé, D. G., Schreurs, P. J. G., \& Schaufeli, W. B. (1997). Stress en burnout bij docenten: Een literatuuroverzicht [Stress and burnout among teachers: a literature review]. Gedrag en Organisatie, 10, 247-256.

Van Horn, J. E., Schaufeli, W. B., \& Enzmann, D. (1999). Teacher burnout and lack of reciprocity. Journal of Applied Social Psychology, 29(1), 91-108.

Yalom, I. D. (1980). Existential psychotherapy. New York: Basic Books. 